\title{
Tolerance of Religious People in Nusa Jaya Villages, District III of Belitang, South East Regency, South Sumatera Province at 1961-2013
}

\author{
Agus Susilo ${ }^{1}$ \\ 1 History Education Departement, STKIP PGRI Lubuklingga, Palembang \\ 1 agussusilo594@yahoo.co.id
}

\begin{tabular}{ccc}
\hline Received & Accepted & Published \\
$12 / 04 / 2017$ & $15 / 06 / 2017$ & $31 / 07 / 2017$ \\
\hline & DOI & \\
& $10.26523 /$ yupa.v1i2.65 \\
\hline
\end{tabular}

\begin{abstract}
This research described how life tolerance of religion in Nusa Jaya Village Belitang District III Regency OKU East Sumatera Selatan, besides to know the factors that cause success tolerance of religion in Nusa Jaya Village Belitang District III Regency of OKU East of South Sumatera. Tolerance is a problem that often arises throughout the time, especially tolerance among religious people. Historically, the religious nature of tolerance does not just appear. This research aims to determine the factors that lead to the success of religious, between Islam, Catholicism, Protestant Christianity, and Buddhism in the Nusa Jaya village, District III of East Belitang, District of OKU, South Sumatra. The method used in this study is the historical method, obtained through in-depth interviews, documentation and literature study. The results showed that normatively the basic values that form the basis of the establishment of tolerance among religious people is the value of religion and cultural Javanese descendants. While empirically composed of human values, nationalism, historical, exemplary public religious leaders and the value of patience.
\end{abstract}

Keywords: tolerance, religious people, nusa jaya village, community life

Abstrak Penelitian ini menggambarkan bagaimana kehidupan toleransi agama di Nusa Jaya desa Belitang Kecamatan III Kabupaten OKU timur Sumatera Selatan. Selain itu, untuk mengetahui faktor-faktor yang menyebabkan kesuksesan toleransi agama di Nusa Jaya desa Belitang Kecamatan III Kabupaten dari OKU East of Sumatera Selatan. Toleransi merupakan masalah yang sering muncul sepanjang waktu, terutama toleransi antara umat beragama. Penelitian ini bertujuan untuk mengetahui faktor-faktor yang mengarah ke keberhasilan keagamaan, antara Islam, Katolik, Protestan Kristen dan Buddha di desa Nusa Jaya Distrik III Belitang Timur, Distrik OKU, Sumatera Selatan. Metode yang digunakan dalam penelitian ini adalah metode yang bersejarah, yang diperoleh melalui wawancara mendalam, dokumentasi dan studi literatur. Hasil penelitian menunjukkan bahwa secara normatif nilai-nilai dasar yang terbentuk di masyarakat dikarenakan toleransi antara umat Bergama dan kebudayan Jawa yang berkembang. Sedangkan, secara empiris terbentuk nilai kemanusiaan, nasionalisme, Sejarah, teladan umum pemimpin agama dan nilai kesabaran.

Kata Kunci: toleransi, kehidupan beragama, Desa Nusa Jaya, kehidupan masyarakat 


\section{INTRODUCTION}

Belitang sub-district is located in Ogan Komering Ulu Timur (OKUT) Regency in South Sumatera Province which is about $200 \mathrm{~km}$ to the southwest of Palembang city. Belitang III District is one of 16 sub-districts in East Ogan Komering Ulu Regency (OKU). The majority of the residents are transmigration residents who have lived in this place for years. The flow of water from the daily Komering river irrigation division watered thousands of hectares of rice fields.

In 1977, this area of Belitang has changed as a result of the continuous migration of transmigrants totaling at least 130,000 swiftly transmigrants. One of the most important things in the development of this transmigration area is the $40 \mathrm{~km}$ irrigation channel built by the Dutch Government between 1937 and 1943. Fifty percent of the expanded road network is already on the asphalt. The topography of this area is flat and the soil is fertile so it can be harvested twice a year as long as there is irrigation (Hardjono, 1982: 84-87).

History of transmigration to Belitang precisely in the village of Nusa Jaya occurred in 1961. At that time transmigrants came from the island of Java. The large number of transmigrants in Nusa Jaya Village amounts to 250 Head of Family (KK). The existence of transmigration to the island of Sumatra, precisely in the village of Nusa Jaya Belitang district III OKU East South Sumatra, the community inevitably have to deal with different religious adherents. Most villagers of nusa Jaya are transmigration people from Java. Religions are dianutpun vary, but this religion is not from the region of origin, but there is a change of religion at the time was already in the transmigration area on the island of Sumatra (Village Archives, January 1, 2013).

Tolerance is a fundamental belief (creed) in religion, can make as a value and norm. It is said to be a value because tolerance is a description of what we want, worthy, valuable, that can affect the social behavior of the person who has that value. Value (tolerance) can make a norm, which is a benchmark behavior in a particular group. Religious life that is tolerant as well as a basic attitude in social life of society, which is always socialized in the household level, is the primary socialization, and secondary socialization occurs after the primary socialization took place. Living in harmony and helping each other will make life in a world of peace and quiet (Koentjaraningrat, 1988: 145-147).Tolerance is a fundamental belief (creed) in religion, can make as a value and norm. It is said to be a value because tolerance is a description of what we want, worthy, valuable that can affect the social behavior of the person who has that value. Value (tolerance) can make a norm, which is a benchmark behavior in a particular group. Religious life that is tolerant as well as a basic attitude in social life of society, which is always socialized in the household level, is the primary socialization, and secondary socialization occurs after the primary socialization took place. Living in harmony and helping each other will make life in a world of peace and quiet (Koentjaraningrat, 1988: 145-147). 
History shows that religion has a big role in the process of building a nation, but there is also evidence that religion can also be a disintegrative factor for other nations. Conflicts of Catholics and Protestants in Northern Ireland, the Christians-Mironit conflict and Muslims in Lebanon and the conflicts of Hindus and Muslims in India are the latest examples we can see. In Indonesia, Muslims and Christians (Catholic and Protestant) can work together to help overcome national problems that require a common solution (Machnun 1986: 215-225).

Social interaction has a correlation with norms, but also with status in the sense that status gives shape or patterns of interaction. Changes in society can occur because of certain movers. Many things can make people think that produces ideas, ideas and beliefs and technology. The changes occurring in the world are basically attributed to this factor and are supported by the first and greatest discovery of language that provides the ability to communicate (Taneko 1993: 135-139).

Based on the above background, the researchers considered it necessary to conduct research on the Tolerance of Religious People in the Village of Nusa Jaya Belitang District III East Oku District of South Sumatera 1961-2013 (Donation of Social History Material). The purpose of this research is to know the life of tolerance of religion in Nusa Jaya Village Belitang III District of OKU Timur Regency of South Sumatera and to look for factors that lead to the success of religious tolerance in Nusa Jaya Village Belitang III District, OKU Timur South Sumatera Regency.

In this research will be explained about various matters relating to the geography of Nusa Jaya Village. Nusa Jaya village is a village located in District Belitang III East Ogan Komering Ulu Regency. Nusa Jaya village in 1961 is a village that has flat and wavy land. Nusa Jaya village is located at an altitude of less than 500 meters from sea level. With the condition of flat land the people of Nusa Jaya Village can use it for agricultural land and plantation.

Total Population in Nusa Jaya Village February 1961

\begin{tabular}{|c|c|c|c|c|}
\hline \multirow{2}{*}{ No } & \multirow{2}{*}{ Religion } & \multicolumn{2}{|c|}{ Villager } & \multirow{2}{*}{ Total } \\
\cline { 3 - 4 } & & Male & Female & \\
\hline 1 & Islam & 321 & 320 & 641 \\
\hline 2 & Katolik & 30 & 15 & 45 \\
\hline 3 & Buddha & 20 & 10 & 30 \\
\hline 4 & Kristen Protestan & 12 & 14 & 26 \\
\hline \multicolumn{2}{|l}{ Total } & $\mathbf{3 8 3}$ & $\mathbf{3 5 9}$ & $\mathbf{7 4 2}$ \\
\hline
\end{tabular}

Source: Village Archives, January 1, 1961

The location of the village of Nusa is also very strategic because it is a village close to Belitang III subdistrict and adjacent to Nusa Tenggara Village which connects to the villages in Mesuji Makmur sub-district of OKI Regency. This caused the Nusa Jaya Village to have wide 
access to other areas. The existence of the village of Nusa Jaya close to the Capital District Belitang III in the village of Nusa Bakti is only $3 \mathrm{~km}$, but far with the Capital District which is 45 $\mathrm{km}$ in Martapura City which is the center of government in East OKU district.

Based on data obtained from the Monogram of Nusa Jaya Village Head Office in 2013, the population of Nusa Jaya Village at the time of its arrival to Nusa Jaya Village are:

jumlah

Total Population in Nusa Jaya Village February 2013

\begin{tabular}{|c|c|c|c|c|}
\hline \multirow{2}{*}{ No } & \multirow{2}{*}{ Religion } & \multicolumn{2}{|c|}{ Villager } & \multirow{2}{*}{ Total } \\
\hline & & Male & Female & \\
\hline 1 & Islam & 623 & 621 & 1244 \\
\hline 2 & Katholik & 159 & 151 & 310 \\
\hline 3 & Budha & 71 & 67 & 138 \\
\hline 4 & Kristen Protestan & 13 & 13 & 26 \\
\hline & Total & 866 & 852 & 1718 \\
\hline
\end{tabular}

Source: Village Archives, January 1, 2013

According to data collection conducted in February 2013 by the Local Government of OKU Timur Regency. The population of Nusa Jaya village is 1718 people. In RT 4 Desa Nusa Jaya there are 711 people or $27 \%$ of the total population of Nusa Jaya Village. The large number of residents in RT 4 makes RT 4 become the RT with the largest number of people. This is due to the wide area owned by RT 4, as well as the location of RT 4 which is lying on the roadside and close to the market.

In this research about tolerance of religion in Nusa Jaya Village Belitang III District of East OKU Regency of South Sumatera 1961-2013 (Contribution of Social History Material), the researchers chose 13 people to be interviewed. The interviewees were based on their role in the development of community tolerance in Nusa Jaya Village. The residents from various backgrounds, both village heads, village officials, religious leaders, teachers, entrepreneurs, transmigration communities still exist, to farmers who are the wheels of the economy of the community in Nusa Jaya Village.

The village of Nusa Jaya is a fertile village, with flat land and paddy fields that extend to the life of the people of Nusa Jaya Village. The flat ground is perfect for rubber plantations supported by soil fertility. For rice fields in the village of Nusa Jaya has many areas of rice fields, but the rice field is a rain-fed rice field. Rice fields can only be planted once or twice a year. During the dry season these fields can still be planted with other crops, such as vegetables and crops. The agricultural sector is now heavily diverted to rubber plantations. This is done because the rubber is also suitable to be planted in rice fields, in addition to the flat ground (Map of Nusa Jaya Village, accessed December 28, 2013). 
The community's recruitment in the rubber plantation sector can support the income of the community of Nusa Jaya Village and bring progress to the development of the Nusa Jaya Village development. The village of Nusa Jaya also has many other businesses, such as builders, bur wells, rubber traders, iron welders, and trade. The economic progress of the community of Nusa Jaya village, finally brought about the development for the education of children in Nusa Jaya Village (Gunawan, 10 April 2014).

Although different religion of Nusa Jaya Village residents always stay in harmony and mutual respect. Respect respect in performing worship according to their belief regardless of difference in society. In the interfaith community and belief in God Almighty in Nusa Jaya Village Belitang III district in general, peace and mutual respect, so that the condition of safe and maintained harmony can be maintained in this district (Source: Primary data management results, 2013) .

Religious tolerance means mutual respect and tolerance towards other believers, not forcing them to follow their religion and not meddling in their own religious affairs. In a pluralistic society like Indonesia relations between different groups of people of different customs and religions can not be avoided (Nurhasanah, et al, 2011: 138).

Transmigration in Belitang is a common and voluntary transmigration, since most of the transmigrants are mostly inhabitants with large flooding or volcanic eruptions at the time. In addition, there are also transmigrants from the swakarsa transmigration, as transmigrants are charged for transportation and for clothing and food. Nevertheless, the government's participation as the person in charge of the transmigration program is quite large, such as the provision of houses, rain water reservoirs, and once a month the government provides basic commodities such as rice, eggs, instant noodles and other basic ingredients (Hardjono 1982: 88).

In its development, the village of Nusa Jaya has become a prosperous village because of its natural support and community's expertise in cultivating agricultural land. This then causes residents to stay at home in this village of Nusa Jaya. The kinship system that is still thick from Java such as the mutual help-helping attitude and mutual cooperation between fellow residents to make them feel at home and can still be found until now (Yusman, interview dated February 27, 2013).

The acceptance and strength of the bond between man and nature underlying the unity of society and village government also has a great influence on the spiritual life of the community, so that the westerners call such views "animism". The social control mechanisms in rural areas take place through the socialization of individuals within the community, religious and cultural institutions of society, including education in the family environment, reflected in norms, legal norms, customs, customs, flokways, mores, public opinion (Asy'ari 1993: 129-133). 
Good relationships between humans and living beings will be well established, if there is no oppression, persecution, deprivation of rights among God's creatures. Any loss incurred by his actions means reducing the level and value of his worship, which means less or not able to manage his world well (Fatah 2004: 27).

So it can be seen that tolerance cannot be separated from good moral and ethical human nature. Humans as objects that are actors in social life that affect the environment. Awareness and responsibility will build a nation and a sense of mutual ownership of the environment is the responsibility of all social beings that must be preserved, so that safe and peaceful life will be realized.

Step Ministry of Education makes the subject of history as a compulsory subject in 2013 at SPM seen very significant in the current context. Further, make it a core subject for primary schools starting in 2014. This is in line with the transformation of the national education system, namely KSSR changes to KBSR starting in 2011. This in turn will elevate the position of this subject in the eyes of the public. Supported by Yacob (2010) see the steps require the subject's history aim to standardize historical knowledge in Malaysia, show interest and historical knowledge relevant in every Malaysian life aspect and strengthen Malaysian history legacy which reflects parallel social diversity with 1 Malaysian struggle.

The new format Subject History Paper 1249/3 implemented from 2013. The objective of the Paper 3/1249 history is to provide opportunities for students to answer questions, prevent students from getting marks empty, student can pluck again sentence from textbook and scholarly books about question asked to get score and question enacted based upon from textbook 4 and from 5 . At the same time, teachers can guide students to identify the title of the theme than likely be out of the question that is just a title that can only be developed contents can be asked in the paper 1249/3. Teachers can also help students to choose reading materials that are suitable include textbooks or other academic materials. In addition, the history of paper 3 is weighted $20 \%$ and the time allocated to candidates answered three hours.

According to Mosothwane (1995), the education history of the particular curriculum when it was found that existing curriculum does not meet the goals and needs of a country to cope with the changes that occur in the present and future. Curriculum changes made with the hope of enhancing the quality and efficiency of education. Based on the above statement, it can be concluded that national policy makers are very sensitive to the importance of this subject as a vision of the future in the process of building the unity of the nation and the country. Policies require secondary school students learn history is national education Philosophy to the needs (FPK) looking for the development of physical, emotional, spiritual and intellectual students simultaneously and integrated. Prior to this Historical subject are treated as second class and subjects associated with the students of Arts (Ghani 2008). 
School Inspector's report finds that the subject of history is less interested by the students because it considers the subject very boring and too difficult to understand. The students' quality statement report published by the Malaysian Examinations Board (LPM) in SPM between 2008 and 2009 summarizes the weaknesses in responding to historical questions because of the weakness of students in the mastery of facts and concepts of understanding, content processing and short answers with simple content as well as less skilled discuss and think (Bahari Md Shah, 2011). The statement was supported by Abdul Razak and Abdullah (2000) on 240 students in the Petaling Jaya and Kuala Selangor districts that the students regarded the History subject as an ineffective subject. This response is associated with History subjects that do not provide job security and have no commercial value (Sivachanlingam et al., 2008).

\section{METHOD}

Scientific methods and results apply concepts that view science as a collection of truths obtained systematically on a particular issue through an effective method. Effective methods get the main attention in increasing a knowledge to become a science. Therefore, history as a science must work according to certain paths (stages) which have a method called historical methodology (Yass, 2004: 3).

Historical research will gain maxmum benefit, if used for the purpose of answering research hypotheses proposed by researchers and reconstructing past events and life appropriately and objectively, through research efforts to relocate, evaluate, and interpret data about the past. (Sukardi 2003: 203-204).

The first step in historical research is heuristics. The heuristic is derived from the hierarchical Greek which means to obtain. Heuristics are techniques or ways to find sources that can be obtained through literature studies, direct observation in the field or through interviews (Alian, 2012: 9-10).

According to Kuntowijoyo (1994: 50), heuristics is the knowledge tasked with investigating sources and attempts to gather information on subjects directly related to the problem. According to Notosusanto (2008: 42).

The research tries to find and collect sources related to the above problems, while the source of the author get them from the Central Library of Sriwijaya University, FKIP Library Sriwijaya University, Regional Library in Palembang, Palembang Private Library, Bookstore in Palembang. The books and other sources are obtained through library research. Because the library is a laboratory on the historian (Gottschalk, 1986: 86). In addition to using literature study, the authors also use interviews (interviews) and documentation. According to Fourth Dictionary of Indonesian Language Fourth Edition (MoNE, 2008: 1559), interview technique 
used in qualitative research is in-depth interview. In-depth interviews are the process of obtaining information for the purpose of research by questioning and face-to-face manner between the interviewer and the informant or the interviewee, with or without using the interview guide, in which the interviewer and the informant are involved in the social life a relatively long time (Sukardi, 2003: 79).

In this study, the research will conduct direct interviews with village officials, community religious leaders and transmigrant communities in the village of Nusa Jaya Belitang District III East OKU district to obtain complete power and information about the object to be studied.

In using historical sources, it should evaluate or critique the sources used. Source criticism is the process of testing the source, whether the source is genuine or false (external criticism) and whether it is trustworthy or accountable or not (Alian, 2012: 11). There are two kinds of criticism: External Criticism and Internal Criticism. External criticism is investigating to determine authenticity by answering $5 \mathrm{~W}+1 \mathrm{H}$ questions. While internal criticism is the determination of whether or not the information in the document is used as a historical fact (Yass, 2004: 35-36).

According to Fourth Dictionary of Indonesian Language Fourth Edition (Depdiknas, 2008: 742), external criticism is a research phase based on physical coverage in the form of description of the form, type of script, material, environment, and environment, the location of the inscription. If the source is a written source such as a book, then the researcher should look at things related to the outward appearance that includes paper, ink writing sentence, style of language / spelling used by the author (Kuntowijoyo, 1995: 99). According to the Fourth Indonesian Dictionary of the Fourth Edition (MoNE, 2008: 742), internal criticism is a working phase based on field data coverage that builds both written sources and epigraphic analogy. Internal criticism is an attempt of analysis to answer questions concerning the accuracy, value of the documents, and the legacy authesis that has been obtained from the field (Sukardi, 2003: 206).

The third step in historical study is Interpretation. Interpretation is required so that dead data can speak or have meaning. Interpretation there are two kinds, namely analysis and synthesis (Kuntowijoyo, 1994: 100). After the process of heuristic, interpretation, and critical sources as the final stage in the method of history is a technique of writing or known as historiography. Historiography is an imaginative reconstruction of the past based on data obtained by taking the process (Gootschalk, 1986: 32). Report writing is organized on the basis of serialization (chronological, causal, and imaginary). Historical writing should be arranged chronologically, so it is important that historical events are not very important and tend to be done on a systematic basis (Kuntowijaya 1995: 103). 
In this activity the researcher uses a social approach, an approach that is directed to use social facts concerning the state of society with the informant's explanation, as proposed by Soejono Soekanto (1982: 162), that: "In studying society, will have much to do with social groups, whether small like family groups or large groups such as village communities, urban communities and others ".

Religious approach is religion used to get involved in solving various problems faced by mankind. The religious approach aims to photograph and understand the truth (Ali, 2002: 92).Geographical approach is used to see the location of an area and the state of nature where an event occurs. In this approach can be seen the area of Nusa Jaya Village is a farm and plantation area.Anthropological approach is to learn the patterns in people's lives. This anthropological approach depicts a simple group of humans covering all aspects of its interconnected culture (Romdon, 1996: 119).

\section{RESULT}

\section{Inter-Religious Tolerance in Nusa Jaya Village Belitang District III East OKU District}

Harmony and tolerance among religious people is an essential need of a universal humanity, which can not be denied and must be endeavored by every human being because human beings are essentially living beings who always need each other in the community (Hasan, 2005: 273).

The village of Nusa Jaya is a village whose inhabitants are transmigration communities from various regions of Java Island. In its history, this transmigration occurred in 1961. Along the development of the era and the division of Nusa Jaya Village into a developed and developing village. This is because the support of agricultural land and plantations and the nature of Javanese people who live in Nusa Jaya village always work hard in building the village until it becomes a developed village and known to other areas (Gunawan, interview dated February 25, 2014).

Religion gives meaning to the lives of individuals and groups, also provides survival after death. To appreciate the freedom of religion as a result of the basic rights of all human beings, serious attention is required from all countries to enhance the dignity of all human beings. Religion is very important for humans, but also must see human beings as dignified beings (Khanif, 2010: 69).

The life of the people of Nusa Jaya village has always been marked by different backgrounds, where the religion of the people of Nusa Jaya village has four religions: Islam, Catholicism, Buddhism and Protestantism. In the early history of his arrival in 1961 in the village of Nusa Jaya, 750 people embraced Islam, embracing the Catholic religion there are 188 souls, Buddhists have 113 souls and 75 people embrace the religion of Protestantism. But the 
difference does not create problems for the residents of Nusa Jaya Village. Harmony of religious people is maintained, they do all their duty according to their obligations without interfering in the affairs of other people's worship (Village Archives, 27 February 2014).

In chapter 6 it says that:

"The Deliberation Council talks about all the common responsibilities and cooperation among the various religions, and with the Government, based on the Pancaasila and the 1945 Constitution in promoting unity and our unity and integrity as a nation and the implementation of the Pancasila Guidance and Practice Guidelines (P4) and the Guidelines of State Policy (GBHN), and other provisions of the government, especially those concerning the religious field" (Puslitbang, 2012: 26)

The harmony of the religious life can only be achieved if each group is chapters to one another. The chest-grace in religious life will have meaning for the life and progress of plural society, when embodied in attitudes that are translated in attitudes, refraining from each other's teachings, beliefs and customs, which may be contrary to the teachings, beliefs and customs , mutual respect for the rights of others to profoundly adhere to the teachings of their religion, mutual trust in the good faith of other religious groups (Taher, 1997: 9).

The history of religious tolerance in the village of Nusa Jaya is also supported by the nature of the Javanese descendants who do not question the differences of religion in society because all religions alike teach the good. The nature of the Javanese descendants who emphasize tolerance in living relationships. At that time, the people in Nusa Jaya village came from Java. The culture of syncretism (the fusion of different streams) of religious tolerance can develop well, so until now relationships can be seen in different family relationships of beliefs (Susilo, interview 27 February 2014).

Tolerance can be interpreted as an attitude to be able to live with other adherents of the religion, having the freedom to practice their religious principles (worship) respectively, without any coercion and pressure, whether for worship or not worship, from one party to another. Tolerance is reflected in mutual respect, mutual respect and mutual help (Taher, 1997: 9).

All religions in the village of Nusa Jaya are nice and respectful in their sense of tolerance and togetherness. The attitude and behavior of excessive fanaticism is very much against the noble values of Indonesian culture and identity that are familial, hospitable, helpful and so on (Khosim, interview February 23, 2014).

Mutual cooperation activities, all the problems and complicated work will be quickly resolved if the cooperation and mutual cooperation between people in the community. The development of Nusa Jaya Village will also be accomplished quickly if the people in it work together and participate in the development activities (Gunawan, interview dated 27 February 2014). 
In the Qur'an it is mentioned that:

Cultivate you in the work of good and piety, and do not cooperate in sinning and enmity (Q.S.Al-Maidah: 2)."

In the Gospels

"He lives with the excommunicado (considered sinful), teaches for the love of neighbor and prayer for the obedient (Matt.9,9-13; Matthew 5. 43-48; 43-48; Mark 2. 2.13-17). "

"Help to bear your burden! Thus you are fulfilling the law of Christ (Galatians.6-1-19). "

In Buddhist philosophy it is mentioned that:

"Unite in the Buddhist path of humanity, justice and peace of love (Deputhera, 1985: 20)."

So it can be seen that the activities of mutual cooperation between religions is one of the key to the creation of tolerance life among religious people. Gotong-royong can foster a sense of togetherness and social solidarity, besides any religion also encourages people to work together in social life. The community of Nusa Jaya Village is one example of the village community who still implement cooperative life among other villages.

\section{Factors that led to the success of religious tolerance in the village of Nusa Jaya Belitang District III East OKU district of South Sumatra.}

Harmony is a common need that can not be avoided amid differences. The differences are not a barrier to living in harmony and side by side in a framework of brotherhood and unity. Awareness of the harmony of religious life that must be dynamic, humanist and democratic, in order to be transformed to society among the lower so that harmony is not only felt / enjoyed by the upper circles of the rich alone (Shahid and Daulay, 2012: 7).

Cooperation, conflict and accommodation are three unavoidable possibilities or consequences in every relationship between ethnic and religious groups in Indonesian plural society (Prayitno and Trubus, 2002: 259). Religion is concerned with the efforts of man to measure the depth of his own existence and the existence of nature. Religion gives symbols to humans. The symbols they can reveal are difficult to express, although the essence of religious experience forever cannot be disclosed (Nottingham, 1996: 3-4).

Harmony is essentially a mental attitude expressed in the form of a motivated, motivated attitude of birth. Strongness or absence of harmony depends on motivation. Therefore, discussing the issue of harmony cannot be separated from the motivation of harmony which means to discuss intentions and goals in relation to harmony (Thoyib and Sugiyanto, 2002: 176). The people of Nusa Jaya village are the Javanese descendants who live as farmers. People in Nusa Jaya Village use their farmland to seek sustenance. In the cultivation of agricultural land and plantation Nusa Jaya village community is always together at the time will plant or harvest. For example, the Moslems give Catholic neighbors the work to cultivate their 
plantations, and vice versa also the Muslim communities work in the cultivation of Catholic communities (Tinah, interview 3 March 2014).

According to Von Weise in the book by Al Munawar (2003: 17-18), the religious group is a group of magical or abstract class. Unity in religion as an invisible group is bound by the inner connection between its members which makes the group eternal, for seeing and accepting religion is not as boring but as a vibrant and vibrant spirit of all souls and bodies and has a great influence against its members.

In the community of Nusa Jaya Village with a wide variety of religions embraced by its inhabitants, they live in a peaceful state and without regard to these existing religious differences. This is evident in the time of maintaining the security of Nusa Jaya Village, for example, when the night watch is a mixed night watch between Moslems and Protestant Christians going around to accompany their night watches together (Susilo, interview 27 February 2014).

The realization of religious tolerance is to build and strengthen the bonds between religious believers and maintain good relationships with other human beings. Developing a diverse tolerance attitude in Nusa Jaya Village, that every devotees should practice their religious teachings and rituals freely and without pressure (Suwoyo, interview 3 March 2014).

In unifying all the young people in the village of Nusa Jaya then held Karang Taruna that can unite the youth. They can hold many events or activities regardless of race, race, or religion. So through Karang Taruna, the youth of Nusa Jaya village can have unlimited creativity. Coral karuna in Nusa Jaya village is a gathering place for young people from all religions in Nusa Jaya Village. Greetings have become commonplace, there is no difference between them. Through Karang Taruna in the village of Nusa Jaya is often held events such as race ball volleyball and soccer is very popular among young and old in the village of Nusa Jaya (Mardiono, interview February 28, 2014). Harmony is essentially a mental attitude expressed in the form of a motivated, motivated attitude of birth. Sturdy or not harmony depends on the motivation. Therefore, discussing harmony which means talking about intentions and goals in relation to harmony (Thoyib and Sugiyanto, 2002: 170).

According to Gunawan (Interview on February 25, 2014): "Religious tolerance is very important to maintain harmony in Nusa Jaya Village. Religion is a free choice of each individual and every religion is true except for a religion that teaches the value of evil. As a social human being must necessarily live a complex society of values because it consists of various tribes and religions. Gunawan's opinion is in accordance with Soerjono Soekanto which explains that tolerance is an attitude that is a manifestation of self-understanding of the attitude of others who are not approved. 
Building the harmony of religious life is an inexorable one. This is because the teachings of their own religion do not teach adherents to be hostile to other religions. Humans in a sociocultural perspective are social beings and cultural beings (Al Munawar, 2003: 56). So it can be concluded that tolerance can grow and not fade with implanted to the generation through institutions or organizations which is a container in establishing communication.

\section{CONCLUSION}

After seeing the description on the discussion about religious tolerance in the village of Nusa Jaya Belitang District III East OKU district. The life of religious tolerance in the village of Nusa Jaya is very good and well preserved. The life of people with religious diversity has been going on since 1961, where the district of Belitang, especially the village of Nusa Jaya is a transmigration area of the population from the island of Java. Through this transmigration program, residents are introduced to a new atmosphere. In this new area, residents must socialize with other transmigrant residents, until finally community life with mutual help-help can be realized. The village of Nusa Jaya is a village that has four kinds of religions adopted by its people. Religion embraced by the community of Nusa Jaya Village is the religion of Islam which is the most widely embraced by the people of Nusa Jaya Village, then Catholicism, Protestant Christianity, and Buddhism developed until this. The nature of religious tolerance in the village of Nusa Jaya is very well developed by the community. Religion is not their obstacle to unity and help each other in the problems faced by people in need of help. Developing an attitude of tolerance and mutual help will create a harmonious relationship among the community in this Nusa Jaya Village.

The tolerance of religious communities in the village of Nusa Jaya is very successful, this is because the people of Javanese descent in the village of Nusa Jaya always maintain harmony among religious people and cooperate with each other even though not religious. In addition, the success of religious tolerance in the village of Nusa Jaya is also supported by four factors that make religious tolerance life can be realized in this Nusa Jaya Village. The four factors supporting the religious tolerance of the village of Nusa Jaya are the social conditions of the community of Nusa Jaya Village, the communication of the people of Nusa Jaya Village, the awareness of the religious leaders in Nusa Jaya Village, and the role of Karang Taruna in Nusa Jaya Village.

\section{REFERENCES}

Alian, Sair. 2012. Methodology of History and Histiography. Palembang: SP4 Project Sriwijaya University.

Al Munawar, Sagil Agil Husin. 2003. Fikih Interfaith Relations. Jakarta: Ciputat Press. 
Village Archives, January 1, 1961

Files. 2012. District Belitang III Dalam Figures Year 2011/2012. Nusa Bakti: Belitang District Head Office III.

Ash'ari, Sapari Imam. 1993. Sociology of the City and Village. Surabaya: National Business.

Diputhera, Oka. 1985. Image of Buddhism In Pancasila Philosophy. Jakarta: CV. Lake Batur.

Monographic Data of Nusa Jaya Village, February 2013

Depdiknas. 2008. Big Language Dictionary Indonesia Center for Fourth Edition Language. Jakarta: Gramedia Pustakan Utama.

Fatah, Abdul. 2004. Human Life in Middle of Nature Material. Jakarta: Rineka Cipta.

Gottschalk, Louis. 1986. Understanding History. Jakarta: University of Indonesia.

Hardjono, Joan. 1982. Transmigration from Colonization Until Swakarsa. Jakarta: PT

Hasan, Hamka. 2013. Jurnal Bimas Islam. Jakarta: UIN Syarif Hidayatullah. 